\title{
IDENTIFICATION OF ADDITIONAL DIAGNOSTIC FEATURES OF THE ANATOMICAL STRUCTURE IN THE RAW MATERIAL OF PHLOMIS PUNGENS WILLD.
}

\author{
Yu.B.Kerimov, A.S.Shukurova \\ Azerbaijan Medical University \\ Key words: microscopy; diagnostic features of the anatomical structure; Ph. pungens Willd
}

\begin{abstract}
The study to identify the additional diagnostic features of the anatomical structure in the raw material of Phlomis pungens Willd. has been conducted. As a result, the specific features of the seed, bract, the inner and outer sides of the corolla, calyx and leaf blades, petiole of the leaf blade have been identified. The characteristic signs are the form of the hairs and the difference of their arrangement on inner and outer sides of the corolla and calyx. The seeds have four oppositely arranged grooves, at the base there are simple hairs. The bract is covered with multicellular branched hairs, its apex is covered with straight simple hairs.
\end{abstract}

Currently, the demand for the plant raw material at the world market is increasing annually. Therefore, it is necessary to identify new areas of growth and determine the resource potential of medicinal plants.

When identifying new areas of the species used it is necessary to conduct a comparative pharmacognostic study of the raw material and determine its compliance with the requirements of the pharmacopoeial monograph. Naturally, new areas of growth are located in other bioecological conditions, that is why the change in the chemical composition is possible, as well as appearance of other diagnostic features of the anatomical structure.

The essential oil, the amino acid and trace element composition, flavonoids, as well as other biologically active substances (BAS) of Ph. pungens Willd. were previously studied $[3,5]$.

After identifying regions of the mass growing of Ph. pungens Willd. within the territory of Azerbaijan the necessity of its study in a comparative pharmacognostic aspect has arisen. The scientific literature provides information about the diagnostic features of Ph. pungens Willd. [1, 4]. Such elements of anatomical diagnosis as

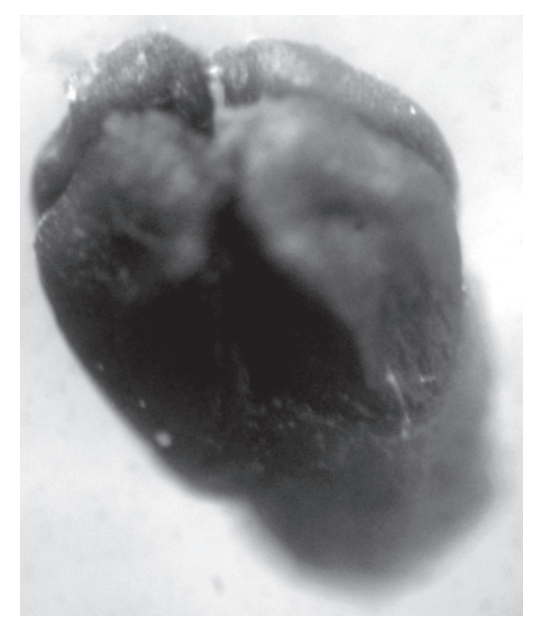

Fig. 1. The seed of Ph. pungens Willd. with four oppositely arranged grooves, at the base there are simple hairs (MBC-1 binocular). sinuosity of epidermal cells, various forms of hairs and stomata are given. However, they are not specific for the species, and are typical for the representatives of the Lamiaceae family. The herb of Ph. pungens consists of leaves, stems, inflorescence and seeds. Therefore, we think it is insufficient and unreasonable to characterize the raw material only by features of the leaf structure. On this basis it is expedient to determine diagnostic features of the anatomical structure in the aerial organs of the plant comprising the plant raw material.

The aim of our work was to study the aerial organs of $P h$. pungens Willd. and to determine diagnostic features of the given species.

\section{Materials and Methods}

The object of the study was the dried herb and seeds of Ph. pungens Willd. collected in the phase of full blossom and fruiting in the vicinity of the Khizi District of the Republic of Azerbaijan. The anatomical structure was studied using the well-known method [2]. The raw material was preserved in the mixture of alcohol - glycerin - water $(1: 1: 1)$, clarified by boiling in $3 \%$ aqueous solution of sodium hydroxide, the microslide was ex-

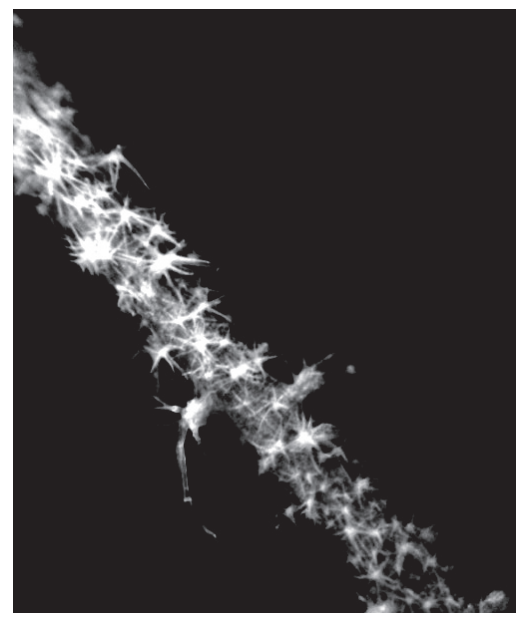

Fig. 2. The bract of $P h$. pungens Willd. with hairs (MBC-1 binocular). 


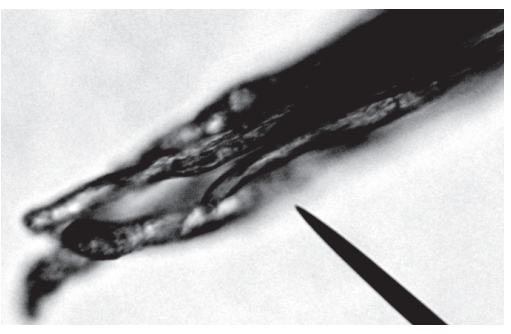

Fig. 3. The hairs on the serrature of the Ph. pungens Willd. calyx. Microscope (x80).

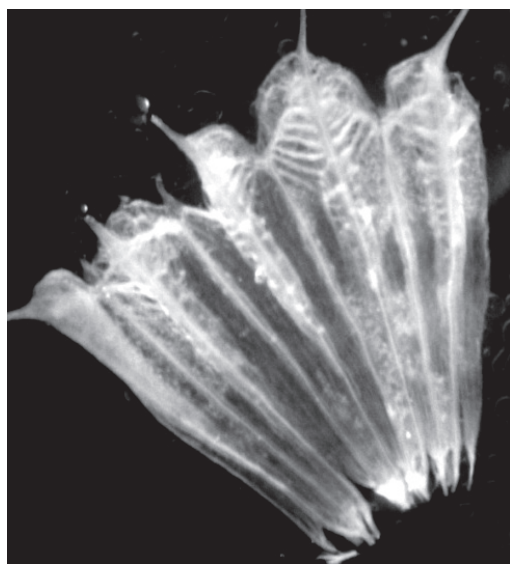

Fig. 4. The calyx of Ph. pungens Willd. is entire. Binocular.

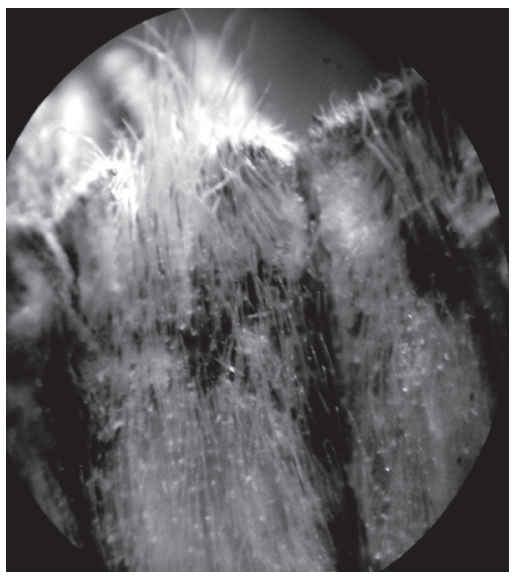

Fig. 5a. The calyx of Ph. pungens Willd. from the internal dorsal side. Binocular.

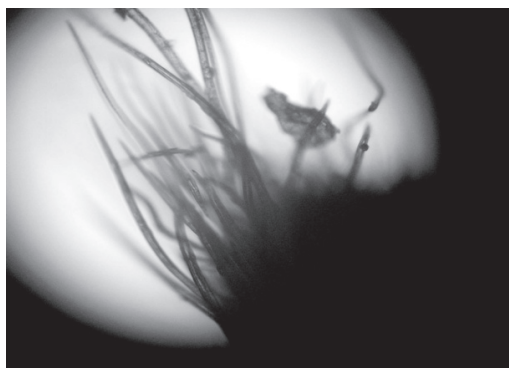

Fig. 5b. The calyx of $P h$. pungens Willd. from the internal dorsal side. Microscope.

amined in the solution of chloral hydrate. The diagnostic features were determined using a "MOTIC SFC-18 SERIES" microscope, as well as MBC-1 binocular. Images of microslides were recorded with a SAMSUNG L74 WIDE digital camera.

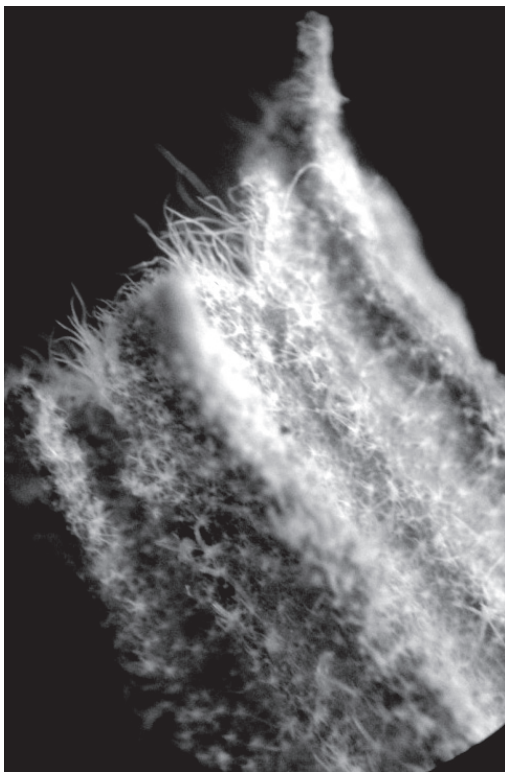

Fig. 6. The calyx of Ph. pungens Willd. - the outer side of the upper part. Binocular.

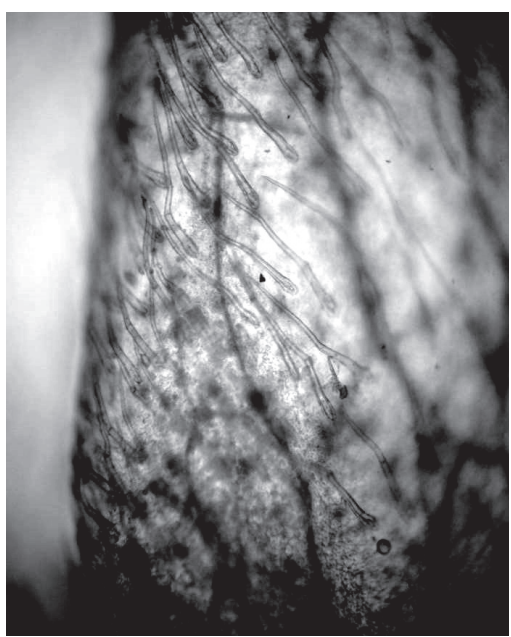

Fig. 7a. The corolla of Ph. pungens Willd. - the internal dorsal side. Microscope.

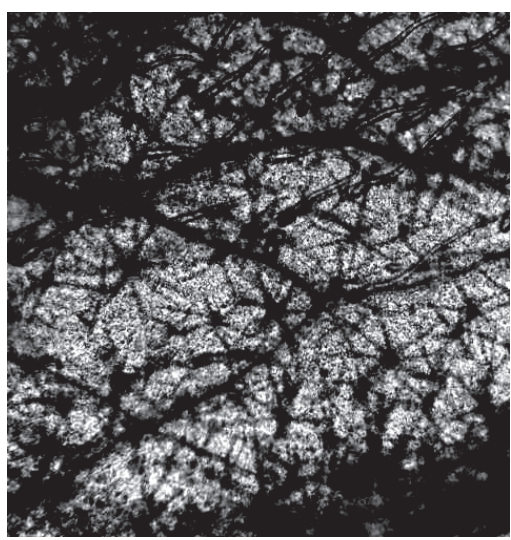

Fig. 7b. The corolla of Ph. pungens Willd. - the bottom of the inner side. Microscope.

\section{Results and Discussion}

At the top the seeds have four oppositely arranged grooves streching to their base. The outer surface of seeds is smooth, glossy, covered with hairs at the base. (Fig. 1) 


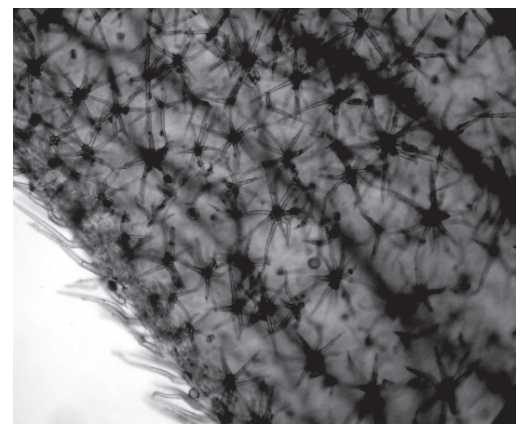

Fig. 8. The corolla of Ph. pungens Willd. - the outer side. Microscope.

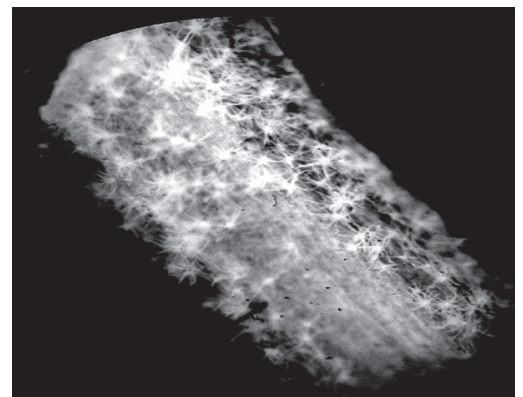

Fig. 9. The petiole of Ph.pungens Willd. Binocular.

The bract is of elongated lanceolate form, the surface is densely covered with multicellular branched hairs (Fig. 2).

Serratures of the bract are covered with straight simple hairs (Fig. 3).

The calyx is entire, serratures of the calyx end with elongated thin edges (Fig. 4).

The calyx from the internal dorsal side is covered with multicellular simple hairs (Fig. 5a, 5b), and there are branched hairs outside (Fig. 6).

The corolla in the internal dorsal side is covered with simple hairs, and there are branched hairs at the bottom (Fig. 7a, 7b).

Outside the corolla is covered only with branched hairs (Fig. 8).

The petiole is covered with a continuous layer of branched hairs (Fig. 9).

The dorsal side of the leaf blade is covered with a dense layer of hairs, and the lower one is less covered (Fig. 10a, 10b).

There are glands along the edges of the leaf blade (Fig. 11).

\section{CONCLUSIONS}

1. The surface of the seeds is glossy and covered with simple hairs at the base; there are four oppositely arranged grooves.

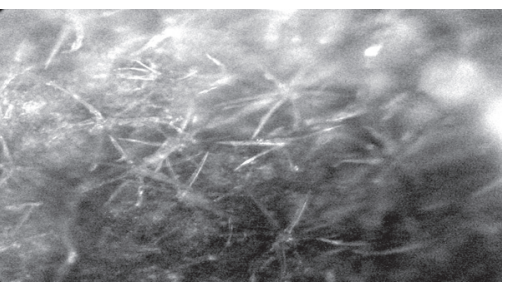

Fig. 10a. The dorsal side of the leaf blade of $P h$. pungens Willd. Microscope.

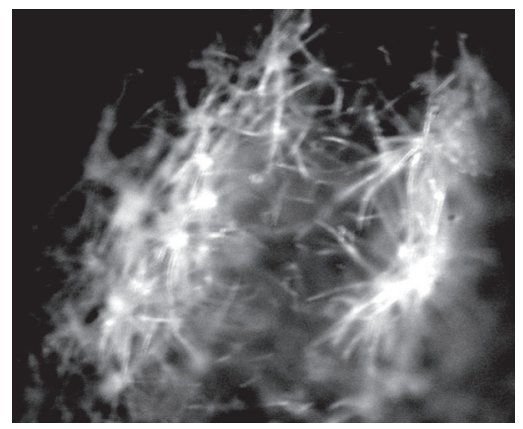

Fig. 10b. The bottom side of the leaf blade of $P h$. pungens Willd. Microscope.

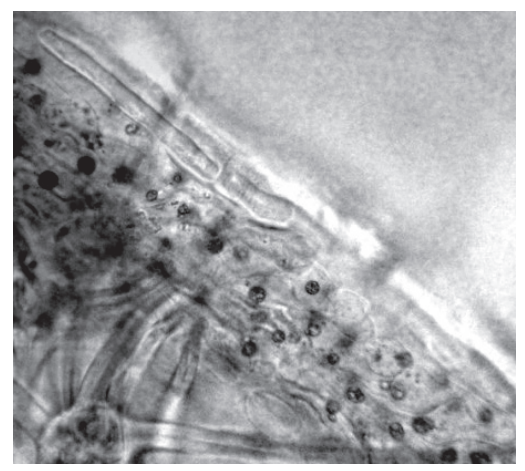

Fig. 11. The edge of the leaf blade of $P h$. pungens Willd. Microscope.

2. The surface of the bract is densely covered with hairs, and its apex ends with simple hairs.

3 . The calyx from the internal dorsal side is covered with multicellular simple hairs, and there are branched hairs outside.

4. The corolla in the internal dorsal side is covered with simple hairs, and there are branched hairs at the bottom. Outside there are only branched hairs.

5. The petiole is covered with a continuous layer of branched hairs.

6. The dorsal side of the leaf blade is covered with a dense layer of hairs; there are glands along the edges of the leaf blade. The bottom side of the leaf is also covered with hairs, especially the midrib.

\section{REFERENCES}

1.Круглая А.А. // Фармачия. - 2007. - №8. - С. 14-16.

2. Практикум по фармакогнозии /Под ред. В.Н.Ковалева. - Х.: Изд-во НФаУ; Золотые страницы, 2003. - 512 c.

3. Kırımer N., Süleymanov T.A., Şükürova A.S. // Azərbaycan Әczaçılıq və Farmakoterapiya Jurnal. - 2013. №2. - S. 22-25.

4. Özdemir C. // Sci. Res. and Essays. - 2011. - Vol. 6 (24). - P. 5168-5178.

5. Süleymanov T.A., Şükürova A.S. // Azərbaycan Әczaçılıq və Farmakoterapiya Jurnalı. - 2014. - №1. - S. 34-40. 


\section{ВИЗНАЧЕННЯ ДОДАТКОВИХ ДІАГНОСТИЧНИХ ОЗНАК АНАТОМІЧНОЇ БУДОВИ СИРОВИНИ PHLOMIS PUNGENS WILLD. \\ Ю.Б.Керімов, А.С.Шукюрова}

Ключові слова: мікроскопія; діагностичні ознаки анатомічної будови; Ph. pungens Willd. Проведене дослідження з визначення додаткових діагностичних ознак анатомічної будови сировини Phlomis pungens Willd. Встановлені специфрічні ознаки насіння, приквітка, внутрішнього та наріжного боку віночка, чашечки квітки і листкової пластинки, черешка листкової пластинки. Характерною ознакою є форма волосків та їх розташування на внутрішніх і наріжних боках віночка і чашечки квітки. Насіння має чотири супротивні борозенки, біля основи $\epsilon$ прості волоски. Приквіток вкритий багатоклітинними гіллястими волосками, а кінчик прямими простими волосками.

\section{ОПРЕДЕЛЕНИЕ ДОПОЛНИТЕЛЬНЫХ ДИАГНОСТИЧЕСКИХ ПРИЗНАКОВ АНАТОМИЧЕСКОГО СТРОЕНИЯ СЫРЬЯ PHLOMIS PUNGENS WILLD. Ю.Б.Керимов, А.С.Шукюрова}

Ключевые слова: микроскопия; диагностические признаки анатомического строения; Ph. pungens Willd.

Проведено исследование по выявлению дополнительных диагностических признаков анатомического строения сырья Phlomis pungens Willd. В результате установлены специфические признаки семян, прицветника, внутренней и наружной сторон венчика, чашечки цветка и листовой пластинки, черешка листовой пластинки. Характерным признаком является форма волосков и их расположение на внутренних и наружных сторонах венчика и чашечки цветка. Семена имеют четыре супротивно расположенные бороздки, у основания имеются простые волоски. Прицветник покрыт многоклеточными ветвистыми волосками, а кончик - прямыми простыми волосками. 